\title{
Refugiados e migrantes na Luanda contemporânea
}

\author{
Dagoberto José Fonseca \\ Professor livre docente da Universidade Estadual Paulista, Brasil \\ dagobertojose@gmail.com \\ Simone de Loiola Ferreira Fonseca \\ Mestre em Sociologia pela Universidade Estadual Paulista, Brasil \\ sferreira77@gmail.com
}

Resumo O artigo, ao abordar o debate acerca dos refugiados e das migrações, demonstra os deslocamentos populacionais presentes em Angola. Lançamos o nosso olhar para Luanda, considerada a capital mais cara do mundo, tendo sido projetada pelos conquistadores portugueses para ser uma cidade de veraneio e ter no máximo 500 mil habitantes, entretanto, atualmente possui mais de seis milhões de pessoas. A maioria é de migrantes internos, oriundos das áreas rurais, refugiados das guerras de independência e civil, falantes de seis grandes línguas nativas e mais de trinta variantes linguísticas originárias do território nacional. Nesse sentido, a língua portuguesa torna-se também um desafio e uma conquista para os refugiados que não a dominam e necessitam dela em Luanda. Essa capital que, ainda, tem recebido estrangeiros africanos de línguas francesa e inglesa, tais como os namibianos, congoleses, zambianos, senegaleses e de outras regiões do mundo, especialmente brasileiros, portugueses, cubanos e chineses.

Palavras-chave: Luanda, refugiados, guerras, paz, migrações.

\section{Refugiados e migrantes na Luanda contemporânea}

As guerras, mais do que as catástrofes naturais, são constituidoras de multidões de refugiados, bem como as crises políticas, econômicas e sociais são propiciadoras de enormes contingentes populacionais de migrantes. Consideramos primordial afirmar que as migrações são processos que envolvem deslocamentos populacionais contínuos e não são fenômenos novos. Elas estão inscritas na própria conquista do planeta Terra pelas populações 
de Homo sapiens surgidas no continente africano e que forjaram com a sua presença novos espaços territoriais dentro e fora da África nos últimos cento e cinquenta mil anos de história antes da era cristã.

As populações primordiais e migrantes africanas territorializaram, desterritorializaram e reterritorializaram diversos espaços a partir das suas produções culturais, elementos dinâmicos e semânticos que fundam novas e perpetuam as mais antigas relações sociais entre seres humanos. Em suma, a primeira globalização e a mais importante efetuada no planeta terra foram destes africanos, pais da nossa espécie (Fonseca, 2009; 2015).

Este artigo que ora elaboramos, em primeiro lugar quer trazer um novo cenário para o debate contemporâneo acerca das migrações e dos refugiados quando faz uma escolha para demonstrar que os processos de deslocamentos populacionais estão presentes em diversas partes do mundo, não somente no hemisfério norte, especialmente quando consideramos que em muitos casos, eles ocorrem no interior dos próprios continentes e países (Fonseca, 2015).

Esse artigo faz uma releitura sobre o processo de migrações internas e externas que atingiu umas das sociedades africanas mais importantes para a nossa realidade sociocultural brasileira - a sociedade angolana.

Refazemos o nosso olhar crítico e profundamente apaixonado sobre a cidade de Luanda, capital da Província de Luanda e capital da República de Angola, a partir de nossa pesquisa de campo no nosso pós-doutoramento realizado em 2008. Vale salientar de antemão que Luanda é a capital mais cara do mundo e que foi projetada pelos antigos conquistadores portugueses para ser uma cidade de veraneio e ter no máximo 500 mil habitantes, entretanto, atualmente possui mais de seis milhões de pessoas, a maioria de migrantes internos, oriundos das áreas rurais, refugiados das guerras de independência e civil,falantes de seis grandes línguas nativas e mais de trinta variantes linguísticas originárias do território nacional e, ainda, tem recebido estrangeiros africanos de línguas francesa e inglesa, tais como os namibianos, congoleses, zambianos, senegaleses e de outras regiões do mundo, especialmente brasileiros, portugueses, cubanos e chineses.

A cidade de Luanda, para os desavisados, tem sido considerada lugar de caos urbano e/ou de bagunça generalizada na língua e na economia, mas eles com a sua complexidade e diversidade se entendem na sua lógica própria e vão impondo a seu modo o seu estilo de vida; e ao importar outros valores também vão se transformando.

\section{O campo-cenário: um tema}

Ao desembarcar no aeroporto internacional - 4 de fevereiro - em Luanda, no dia 15 de maio de 2008, carregávamos quatro malas com muitas roupas, calçados, gravadores MP3, pilhas, notebook, uma resma de papel sulfite $\mathrm{A} 4$, a disposição para iniciarmos o trabalho de campo e de realizarmos as entrevistas necessárias. 
Buscamos obter informações, reflexões, análises e interpretações de historiadores, sociólogos, antropólogos, economistas, linguistas, jornalistas, advogados, membros do governo, reitores, empresários e estudantes de diferentes cursos. Todos independente de sua condição social, política ou financeira não eram kaluandas, originários da ilha de Luanda, eram migrantes, refugiados e negros, segundo o nosso olhar estrangeiro. Queríamos saber como essa população vivia em Luanda, o que pensavam acerca da paz e do processo de reconstrução do país.

Portávamos um conjunto de questões e sabíamos que teríamos de lidar com desafios metodológicos, além de uma imensa responsabilidade política, compromissos éticos e uma vivência propiciada pela pesquisa de campo. No entanto, esta foi uma das onze viagens técnicas e acadêmicas (científicas, culturais e extensionistas) que fizemos a este país africano, iniciadas desde o ano de 2004.

A cidade de Luanda mantém a mesma aura mágica de quando a conhecemos em 2004, mesmo quando o que se vê e se via nas ruas era que o processo de reconstrução da infraestrutura urbana estava em ritmo acelerado e sendo efetuada por empresas brasileiras e chinesas.

Esta reconstrução ganhava contornos políticos, sobretudo porque tinha um impacto socioeconômico na população, pois sinalizava uma melhor distribuição de renda econômica e a quase garantia de emprego para a população jovem recém-saída da guerra civil. O que se verificava pela mídia governista de Angola a partir da Televisão Popular de Angola (TPA) e pelos jornais impressos era de que a reconstrução da infraestrutura urbana não era uma exclusividade da capital, mas de outras cidades do país, incidindo principalmente sobre a educação com a construção de centenas de escolas públicas (níveis infantil e fundamental) e a extensão das instalações universitárias, na área da saúde (com a construção de vários postos de saúde, hospitais e ambulatórios) e estradas de rodagem para ligar Luanda a diversas províncias no interior.

Constatamos a euforia dos membros do governo e docentes das universidades (pública e privada) com este desabrochar desenvolvimentista do país, pois tudo indicava que Angola, e, particularmente Luanda, estava em busca do seu pleno desenvolvimento econômico em decorrência dos rendimentos do petróleo no mercado internacional, gerando um índice de crescimento no produto interno bruto dos maiores do mundo nos anos de 2007 e 2008, na ordem de 22\% em média.

Esta euforia também ecoava entre os brasileiros residentes em Luanda que se encontravam em reuniões, seguidas de jantares na Embaixada Brasileira, especialmente a que recepcionou a delegação da Comissão de Relações Internacionais do Senado Brasileiro, liderada pelo Senador Heráclito Fortes (DEM-Piauí), à época (maio de 2008). Nessa reunião verificamos na nossa mesa, entre vinhos e whisky, os editores da Revista Lusofonia; o representante do Banco Mundial (Sr. Ricardo Gazel - brasileiro, mineiro da região de Montes Claros); o jornalista Carlos Monforte, contratado para chefiar a 
campanha eleitoral do MPLA ${ }^{1}$ nas eleições legislativas da Assembleia Nacional de Angola; e o Prof. Edílson Marques da Silva, docente licenciado pela UNESP-FAAC/Bauru ${ }^{2}$ para ministrar as disciplinas de marketing e relações públicas no curso de jornalismo da Universidade Independente de Angola (UNIA). Todos mencionavam o grande desempenho econômico de Angola, o seu potencial na SADC ${ }^{3}$ e em todo o continente africano, sendo considerada uma potência regional na região da África Austral, rivalizando com a África do Sul no seu papel de influência política na região.

O representante do Banco Mundial, ainda, considerou que Angola, pelos índices de crescimento, se encaminhava para, em cerca de no máximo 20 anos, ser uma das maiores potências do continente africano, sobretudo pelo fato de ter uma pequena população (aproximadamente 12 milhões de habitantes em 2008) e um vasto território agriculturável, com imensos vazios demográficos, além de ser um país riquíssimo em recursos naturais (minérios); mas também devido ao fato de Angola ter uma população que correspondia a aproximadamente $10 \%$ da população da Nigéria, mas hoje produz uma quantidade de petróleo similar a este país membro da OPEP (Organização dos Países Exportadores de Petróleo) e, além disso, não ter os problemas étnicos que subsistem neste país africano, bem como não ter os dilemas sociais vividos pela África do Sul, na medida em que lá ainda se convive com o resquício do apartheid que continua a dividir negros e brancos de maneira visceral.

Compreendíamos que o governo angolano realizava um grande esforço para continuar tendo os altos índices de desenvolvimento econômico, sobretudo a partir da construção de infraestrutura básica, de investimentos na educação e na saúde de modo massivo, na qualificação social e profissional de sua imensa maioria jovem. Além de constituir instrumentos e mecanismos eficazes para atrair os universitários formados que residem no exterior a voltar ao país para contribuir neste esforço.

Já naquele momento constatávamos que o governo angolano deveria elaborar políticas mais eficientes e ágeis para fazer com que se constituísse um desenvolvimento social com a redistribuição de renda tão necessária para que se pudesse afastar de vez a atmosfera tensa da guerra civil que tinha assolado o país (Jorge, 1998; Roque, 1997).

Em mais de uma reunião que fizemos com Ricardo Gazel, em Luanda, ele considerava que seria interessante se o governo angolano buscasse apoio do Ministério de Desenvolvimento Social e Combate à Fome do Brasil no sentido de intercambiar tecnologias administrativas, estratégicas e sociais no intuito de implantar os programas de transferência direta de renda para a população mais empobrecida de Angola, sobretudo

1 MPLA, sigla de Movimento Popular de Angola, partido do governo desde a independência de Portugal em 1975.

2 UNESP-FAAC-Bauru, sigla de Universidade Estadual Paulista - Faculdade de Arquitetura, Artes e Comunicações do campus de Bauru.

3 SADC, sigla com referência em inglês: Southern Africa Development Community. Integram a SADC 14 países da África Austral. 
vinculando-a as questões educacionais e de saúde, particularmente com relação aos registros de nascimentos e vacinação das crianças.

Além do que, seria importante se o governo angolano buscasse na Embrapa (Empresa Brasileira de Pesquisa Agropecuária) também apoio à tecnologia para a melhoria das condições do solo para plantio e como uma alternativa para a volta ao campo de muitos agricultores que estão em Luanda na condição de refugiados, em decorrência da guerra e da presença das minas nas áreas rurais. Essa era uma das causas dos deslocamentos populacionais em direção à Luanda.

Toda esta análise também estava cercada de dados importantes sobre o período, pois naquele momento, acompanhávamos a violência urbana que se desencadeava em diversas cidades sul-africanas, sobretudo em Johannesburg, como consequência do aumento do desemprego que atingiu os jovens sul-africanos. Eles entendiam que o desemprego era dado pela presença cada vez maior de estrangeiros, migrantes de outros países africanos, principalmente de Moçambique, Namíbia, Zâmbia e Zimbábue.

As impressões dos primeiros angolanos que tive contato, mas também destes brasileiros era de que se vivia um momento especial na história recente de Angola após a instauração da paz efetiva. No entanto, algumas questões permaneciam nas sombras, por exemplo, quais mecanismos criar para incentivar a população refugiada a voltar para as áreas rurais e a produzir alimentos para a sua própria subsistência, com isto se visava diminuir a pressão urbana e o número de musseques ${ }^{4}$ na cidade de Luanda; e, ainda, o que fazer com a imigração de jovens portugueses universitários que fugiam da falência econômica lusitana e buscavam na antiga colônia fazer mais fortuna do que nome, bem como lidar com a imigração de trabalhadores brasileiros e chineses que eram contratados para atender a demanda governamental na área da construção civil.

Figura 1 - Musseque em Luanda

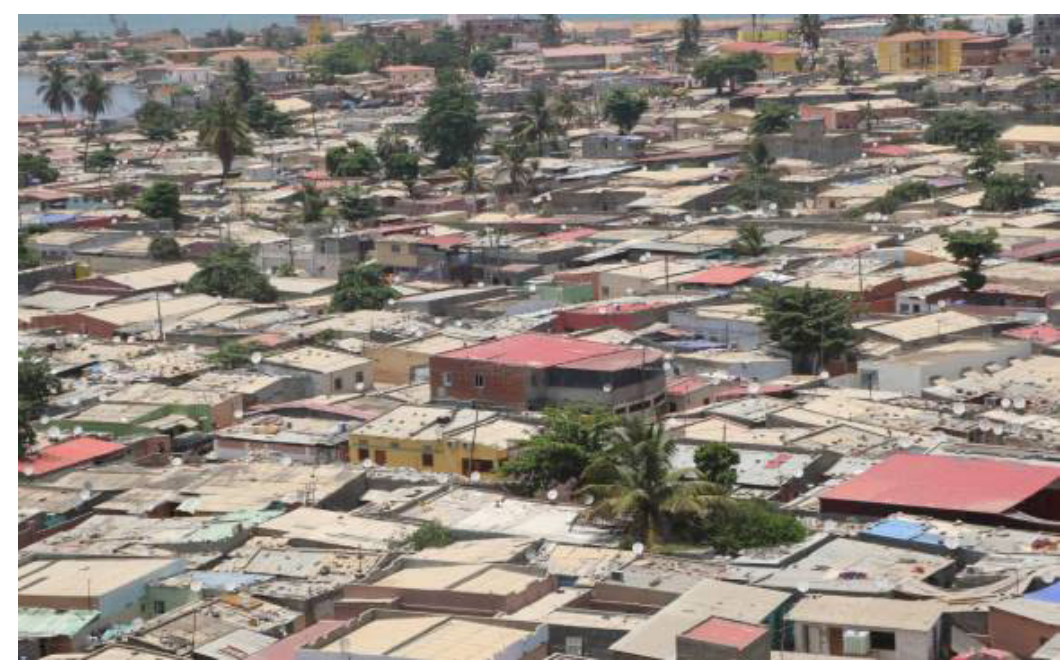

Fonte: Disponível em: <https://www.google.com.br/search?q=musseque+em + Luanda\&client= gmail\&rls=aso\&authuser $=0 \& \mathrm{dcr}=0 \&$ source $=\operatorname{lnms} \& \mathrm{tbm}=$ isch $\& \mathrm{sa}=\mathrm{X} \& \mathrm{ved}=0$ ahUKEwjhrYCkxp7YAhVIQpAKHXxMDnAQ_AUICigB \&biw $=1366 \&$ bih=667\#imgrc $=e Z O a n s F 5 d n t V D M>$. Acesso em: 24 set. 2017.

4 Musseques são áreas residenciais similares às favelas brasileiras. 


\section{Uma pesquisa - seu campo teórico-metodológico}

A pesquisa em foco abriu um campo teórico-metodológico de investigação acerca das perspectivas que constituem os universos culturais, linguísticos e sociais de jovens universitários, intelectuais, literatos, jornalistas, refugiados angolanos e migrantes estrangeiros referentes às suas interpretações sobre as condições sociais, a construção e a manutenção da paz.

Interpretamos a realidade vivida com os dados presentes na bibliografia que selecionamos, com as entrevistas que foram concedidas pelos formadores de opinião buscamos reconstruir o mundo que conceberam e estavam envolvidos, na medida em que são seres de redes sociais e de relações culturais, econômicas e políticas em um mundo que se globaliza, se interage e se toca, friccionando procedimentos e identidades coletivas e plurais, sobretudo em uma cidade como Luanda, que é a capital do país e porta de entrada de diversos produtos e pessoas que são originárias de diversas partes do mundo hiperdesenvolvido, em desenvolvimento e do terceiro mundo.

Observamos e interpretamos a capacidade destes sujeitos sociais em formarem e difundirem opiniões, reflexões, análises e interpretações acerca da cidade de Luanda, bem como do país que é um dos mais novos do mundo, pois se ergueu no início do século XXI com a paz de 2002 e que foi palco de uma das mais terríveis disputas políticas e militares diante o contexto da guerra fria e que envolveu as nações mais poderosas do planeta e três blocos econômico-políticos: o capitalismo euro-ocidental, o socialismo soviético/cubano e o maoísmo chinês (Moore, 2010; Andrade; Ollivier, 1974; Bender, 2004; Golan; Ron, 2007; Pereira, 2015; Michel, 2007).

A teoria e a metodologia que embasam uma pesquisa de cunho interpretativo necessitam dos dados e da experiência do presente, mas também do passado histórico e social da população alvo, dos documentos, reflexões, conceitos e memórias que ela produziu ao longo do tempo.

A base da antropologia interpretativa de Geertz $(1989 ; 1998)$ deu sustentação ao nosso trabalho, a despeito das críticas e das limitações, na medida em que buscamos o significado e o conteúdo simbólico das ações sociais e das reflexões de cada entrevistado a fim de interpretá-lo e compreendê-lo. Deste ponto de vista metodológico não visamos dissecar códigos e signos, nem tão pouco fazer análises ou dar justificativas para a realidade e contexto que apreendemos com nossas observações.

Nesta pesquisa diminuímos a distância entre quem fala e quem ouve. Retiramos a escrita, enquanto meio de comunicação entre o eu (pesquisador/ouvinte/receptor) e o outro (pesquisado/informante/transmissor), à medida que buscamos experimentar as sensações do pesquisado, as caras e as bocas, as mexidas dos olhos, o virar alternado do pescoço, o não encarar, o suor e a secura na boca, etc. que sempre indicavam uma busca de tempo e de um espaço mais arejado em sua reflexão para não ser mal compreendido, mal interpretado futuramente. Portanto, se escolhia as palavras em um repertório vasto da língua portuguesa falada em Luanda. 
Buscamos, de outro lado, suprimir as dúvidas com perguntas insistentes sobre o mesmo tema. Porém, às vezes éramos contemplados com um calão particular, mas também com as interjeições locais e interétnicas que se misturavam ao linguajar destes angolanos cultos e com a formação política e militar (Fonseca, 2012a).

A ideia inicial era deixar tudo nítido, mas também de modo inconfesso era terminar o mais rápido aquela sessão de perguntas, por vezes sagazes, por vezes inteligentes, por vezes simples ou ingênuas, mas sempre complicadas para os olhos da política que se faz cotidianamente em Angola, em particular em sua capital, Luanda. Mesmo que trabalhássemos com a lógica de ouvir os nossos entrevistados sempre onde eles diziam que era melhor e mais confortável para eles.

$\mathrm{O}$ incômodo sempre existiu de uma maneira ou de outra, sobretudo quando se tocava em assuntos da política interna, sem que em nenhum momento perguntássemos diretamente sobre o partido (MPLA), a oposição (UNITA) ${ }^{5}$, sobre o governo e sobre o Presidente.

Neste contexto, lançamos mão do pensamento de Paul Ricoeur $(1978$; 1990) à medida que este dialoga com Gadamer e Habermas para dizermos nas palavras introdutórias de H. Japiassu que o objetivo da hermenêutica que estabelecemos como princípio teórico e como recurso metodológico é de:

atingir e formular uma teoria da interpretação do ser. [...] E esclarecer a existência é elucidar o sentido [...] vale dizer, o da extração e da interpretação do sentido. Percebeu que todo o pensamento moderno tornou-se interpretação. Assim, a questão que se lhe revela essencial não é tanto a do erro ou da mentira, porém a da ilusão. Para se descobrir a verdade, deve-se dissipar essa questão. Toda a crise atual da linguagem pode ser resumida na oscilação entre a desmistificação e a restauração do sentido (Japiassu apud Ricouer, 1990, p. 1).

A concepção que adotamos nesta pesquisa não é a de termos o absolutismo da ingenuidade e nem o da isenção. Não a concebemos como uma pesquisa de orientação política ideológica, posto que seja no discurso que as ideologias e conflitos interpretativos dialogam, se confrontam, mas nem sempre conseguem construir complementaridades, porém conformam situações novas e de mobilidade.

Uma parte considerável de nossos entrevistados sabia que a eleição deles não foi uma escolha aleatória, isenta, ingênua e neutra de nossa parte, sobretudo porque tinham compromissos com a história recente e antiga de Angola e com a atual situação de Luanda, estando assentados em lugares estratégicos e participando de alguma maneira da hegemonia do poder econômico, da cultura e da política administrada pelo governo do MPLA. Muitos deles eram partidários deste único partido político verdadeiramente nacional de Angola.

Outra parte deles não tinha a noção completa do que fazíamos ali, apenas que éramos brasileiros, eram os nossos informantes cotidianos, a maioria composta por refugiados e 
migrantes. Preferimos no caso destes não declinar os seus nomes, até porque não sabemos se nos passaram os verdadeiros nomes, posto que o fundamental não fosse os seus nomes, mas onde estavam situados naqueles momentos de nossos encontros casuais.

Onde trocávamos informações pontuais e nada sistemáticas, nos encontrávamos nas ruas poeirentas, sujas, nos mercados às sarjetas, cheias de crianças amarradas às costas das mães e das agregadas ao longo da Avenida Samba, próximas ao Hospital Maria Pia e acerca de 2 quilômetros de distância da cidade alta, onde se encontrava a Casa Militar comandada pelo General Copelipa e a Residência Oficial do Presidente Eduardo José dos Santos.

Eram constantes os homens também vendendo roupas, utensílios domésticos, pães, bolos e frutas tropicais em plena avenida, ziguezagueando entre os carros parados ou em marcha lenta em decorrência do enorme trânsito.

Figura 2 - Trânsito em Luanda

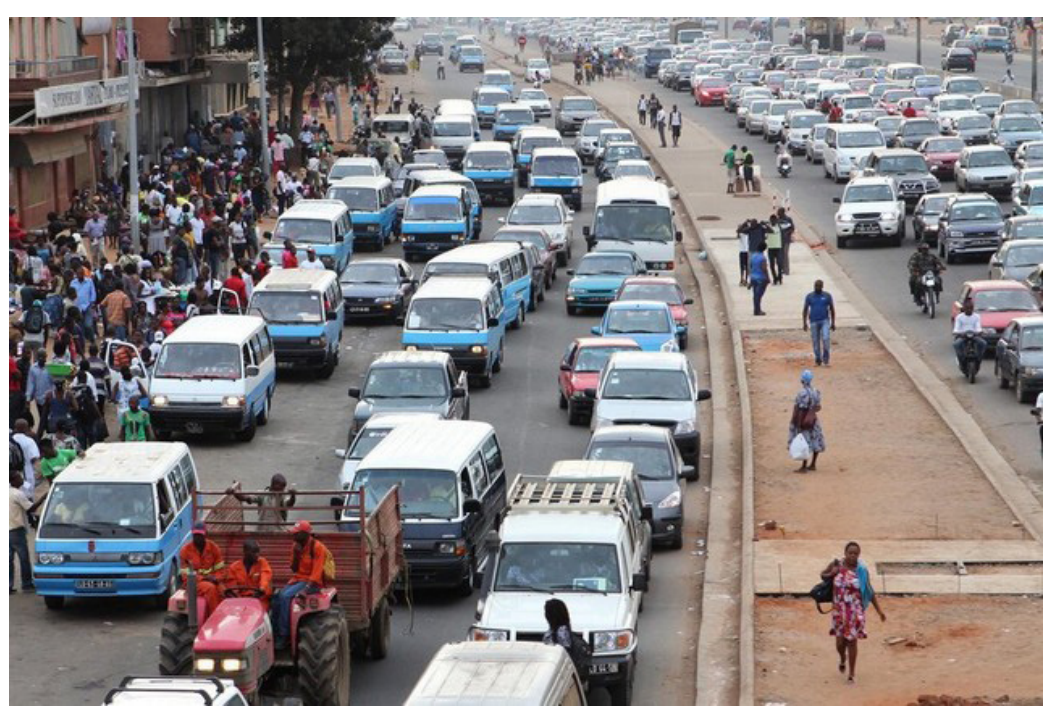

Fonte: Disponível em: $<$ https:/ $/$ www.google.com.br/search?client $=$ gmail\&rls=aso\&authuser $=0 \&$ dcr $=0 \&-$ biw $=1366 \& \mathrm{bih}=667 \& \mathrm{tbm}=$ isch\&sa $=1 \& \mathrm{ei}=\mathrm{Q} 3 \mathrm{c} 9 \mathrm{~W}$ qi1 $\mathrm{I} 4 \mathrm{OCwg}$ ThgbLICA\&q $=$ transito + em + luanda\&oq $=$ transito + em+luanda\&gs_l=psy-ab.12..0i24k1.9348.18597.0.20935.46.29.2.5.6.0.360.3229.0j15j3j1.20.0...0...1c.1.64. psy-ab..22.17.1860.0..0j0i5i30k1j0i30k1.334.21vTgXqC5Dk\#imgrc=ibM6uxDzJ62FVM:>. Acesso em: 24 set. 2017.

Fizemos uma compra inesquecível em 2004, nesse mercado a céu aberto, sem segurança e sem seguro algum. Negócios rápidos são realizados nas ruas, cada um dá um preço e se chega geralmente à média consensuada entre comprador e mercador. Rumávamos para o aeroporto 2 de julho, pois viajaríamos para a Província de Cabinda, no caminho compramos uma bata linda, crendo ser uma autêntica angolana, mas era uma bata "Made in Taiwan".

Todos os carros indo em direção à parte baixa da cidade, rumo às avenidas litorâneas da baía, do Banco Nacional de Angola e do porto de Luanda. Vale dizer que em Luanda, até aquele momento, o único transporte coletivo eram os candongueiros. ${ }^{6}$

6 Candongueiros são os veículos (peruas Kombi ou Kia) de cor azul claro que transportam as pessoas de um ponto a outro na cidade ou da grande Luanda para a capital. 
Não fizemos uma descrição densa dos eventos e dos significados de cada informação dada, mas procuramos os nexos causais, as elocuções-chave, as palavras carregadas de significado a fim de interpretá-las, segundo o contexto e o texto oral produzido pelo pesquisado/entrevistado/informante/transmissor. Elaboramos com isto o entendimento do entendimento, mas a partir da fala do outro.

Foi o entrevistado/informante que transmitiu e elaborou o seu texto com os sons, as incoerências e as dificuldades que ele trouxe para o nosso entendimento, com seus sotaques, ritmos e vícios de linguagem derivados de suas diferentes etnias, presentes no modo de falar o calão, a língua portuguesa que se ergue nas ruas de Luanda.

Diferente de Geertz (1989) deixamos o nativo entrevistado/informante, transmissor do conhecimento e da realidade local, aparecer e falar publicamente ${ }^{7}$. Todos angolanos e negros ${ }^{8}$, sendo oriundos de diferentes regiões do país e possuindo identidades étnicas distintas, mas residindo em Luanda.

O perfil de cada um dos entrevistados demonstra que apenas o Prof. Justino Pinto de Andrade e o Prof.Antônio Bernardes de Miranda, na época contavam com 60 anos, os demais estavam na média etária de 35-40 anos. Com isso, todos, independente da idade, conviveram com o último processo de guerra existente na história recente de Angola, ou seja, aquela que marcou o período de guerra civil capitaneada principalmente pelo MPLA e a UNITA (Golan; Ron, 2007) ${ }^{9}$.

Quanto aos nossos informantes, também tinham a experiência da vida em uma sociedade em plena guerra civil, tanto que se refugiaram em Luanda, e ficavam nas ruas próximas à Casa Militar e à Residência Oficial do Presidente da República, ali se sentiam seguros.

Luanda, assim, recebeu uma população oriunda de várias regiões do país e pertencente a diversos grupos étnicos e falantes das diferentes línguas nacionais e regionais d'Angola (Pereira, 2015). São esses entrevistados que falam da sua realidade, mesmo tendo um limite que é o dado pelo enunciado e pela própria pergunta.

Compartilhamos da tese de Geertz de que:

as ciências sociais estarem recorrendo às humanidades na busca de suas analogias explicativas é, ao mesmo tempo, evidência da desestabilização dos gêneros e de que agora chegou a vez da interpretação. O resultado mais visível

7 Procuramos trazer as ideias mais completas possíveis dos entrevistados, de modo que as citações e fragmentos das entrevistas aparecerão grandes, tomando vários parágrafos para que as suas ideias pudessem ser transmitas sem as interrupções costumeiras em trabalhos acadêmicos. Esta estratégia é para valorizar a reflexão que está sendo feita, bem como para que os leitores possam ter o máximo de informação sobre um tema específico.

8 As exceções talvez estejam no jornalista Neto Jr., que pode ser considerado mulato; e na aluna de economia Érica, que é albina. Eles podem não ser encarados como negros pelos padrões angolanos, mas que se identificam como tal. Eles não se concebem nem mulatos, nem cabritos.

9 Não queremos com isto negar o papel da Frente Nacional de Libertação de Angola (FNLA), que lutou sob o comando de Holden Roberto neste processo. Porém, destacamos o MPLA e a UNITA pela duração e extensão da guerra civil angolana. 
deste processo é que os estudos sociais estão adotando um novo estilo de discurso. Os instrumentos do raciocínio estão se modificando. Representa-se a sociedade cada vez menos como uma máquina complicada ou como um quase organismo e, cada vez mais como um jogo sério, um drama de rua, ou um texto sobre comportamento (Geertz, 1998, p. 38).

Associo a perspectiva metodológica de Geertz quanto a sua visão da pesquisa científica que se preocupa em saber o que se produz enquanto cultura cotidiana e no local dos nativos e seus significados aos estudos da Nova História (Le Goff, 1990; Hunt, 1992) e da Ideologias e mentalidades (Vovelle, 1991), pois esta dimensão da pesquisa também considera a subjetividade, a intertextualidade, as manifestações subterrâneas e o cotidiano como bagagens que permitem compreensões do mundo e dos eventos humanos em sua pluralidade.

Para a interpretação dos (con)textos que fundamentaram os discursos dos entrevistados e informantes residentes em Luanda necessitou-se do diálogo com as demais ciências. O concurso dessas outras ciências "não quis refletir o mero encaixe de disciplinas de forma despreocupada e sem propósitos, mas uma tentativa de fazer a leitura das múltiplas facetas da realidade" (Fonseca, 2012b, p. 14) que podem estar subsumidas no discurso dos entrevistados e dos meus singelos apoiadores em solo angolano.

Com estas metodologias em diálogo interpretamos a sociedade de Luanda, seus microespaços, seu cotidiano, buscando entender os discursos novos e antigos que sustentam esta realidade social que é a vivenciada nessa capital.

Desta maneira, selecionamos os trechos mais significativos dos discursos contidos nas entrevistas a partir de uma coerência con(textual) que propiciasse uma interpretação antropo-histórica da realidade social de Luanda. Realizamos um grande esforço teóricometodológico e um portentoso desafio pessoal e científico à medida que estabelecíamos a relação dialógica entre as ciências da sociedade em um ambiente em constante transformação diante da paz, da globalização e das migrações estrangeiras e dos refúgios internos, processos gestores de novas realidades no cenário dinâmico e multicultural de Luanda.

Em suma, naquele momento estávamos cientes de que poderíamos cometer algumas imprecisões, indeterminações próprias de um trabalho que teria continuidade em Luanda, particularmente porque o nosso edificio teórico-metodológico era permeável o suficiente para receber novas informações que não conseguiríamos captar de imediato, sobretudo porque os meus entrevistados também não são inocentes visto que não são os nativos românticos de Rousseau ou da maioria dos antropólogos de campo, nem tão pouco os informantes das ruas de Luanda eram ingênuos completos. Eles eram homens e mulheres de e da política partidária, social, governamental e estatal de Angola e que residem na capital econômica, o lugar mais seguro do país. 


\section{Ser imigrante e refugiado no seu próprio país - o imperativo da língua}

Os dados da pesquisa e sua interpretação nos colocam diante de um cenário e um contexto bastante singular para compreendermos a realidade social angolana. Os nossos entrevistados/informantes apontam para uma questão fulcral do debate sobre os grandes e contínuos processos de deslocamentos demográficos no país, que é o da construção do refugiado, do imigrante e do estranho em seu próprio território nacional.

Observamos que em Luanda a língua portuguesa, a língua do conquistador, é a que repele e que torna o angolano não oriundo de Luanda, o não kaluanda, o proveniente de outra região do país, e que ao chegar à capital se torna estrangeiro. Destaca-se o fato de que mesmo o kimbundu, originário, por exemplo, da Província do Malanje é considerado um estrangeiro em Luanda, pois não é da Província - sede/capital e tão pouco da ilha de Luanda.

Fica nítido isto nas palavras do jurisconsulto e advogado João Pinto, atualmente deputado da Assembleia Nacional, quando concedeu a sua entrevista em 2008: "não abro mão de comer o meu funji toda a semana com a mão, como se faz no Malanje, sou um autêntico malanjino"; ou quando o Sr. Davi de Leonardo Chivela, à época Diretor Geral do Instituto Nacional de Investigação e Desenvolvimento da Educação (INIDE) do Ministério da Educação, diz:

Bem, mesmo o umbundu eu não falo perfeitamente, porque eu tive a felicidade e infelizmente de nascer na cidade de Lobito. A cidade de Lobito, em termos geográficos é uma cidade de litoral, e quase todas as cidades de litoral não tem o perfeito domínio da língua que fala-se na região. Percebo bastante a língua umbundu porque os meus pais, que falavam enquanto estiveram em vida, então deu para perceber bastante o umbundu. Mas em termos de falar, falo pouco, percebo mais que falar. Não domino quase outras línguas, uma ou outra palavra de outras línguas do kimbundu e de outras línguas vou percebendo por causo do convívio que eu vou tendo. A minha esposa, embora seja da região kimbundu e de Luanda, também vai falando algumas coisas e dar para ir percebendo algumas palavras da língua kimbundu.

Estando nas dependências do Hotel Presidente Meridien, situado defronte ao porto de Luanda, constatamos dois funcionários, sendo que um estava em cima da escada, enquanto o outro embaixo, o que se situava no piso repassava luminárias fluorescentes para o que estava em cima. Eles estavam naquele momento instalando as lâmpadas nos andares no citado hotel, na conversa deles, pudemos ouvir o diálogo jocoso, corriqueiro e profundo, quando um dizia para o outro: Eu poderia estar ai em cima... 
Figura 3 - Vista do Hotel Presidente - Baía e Porto de Luanda

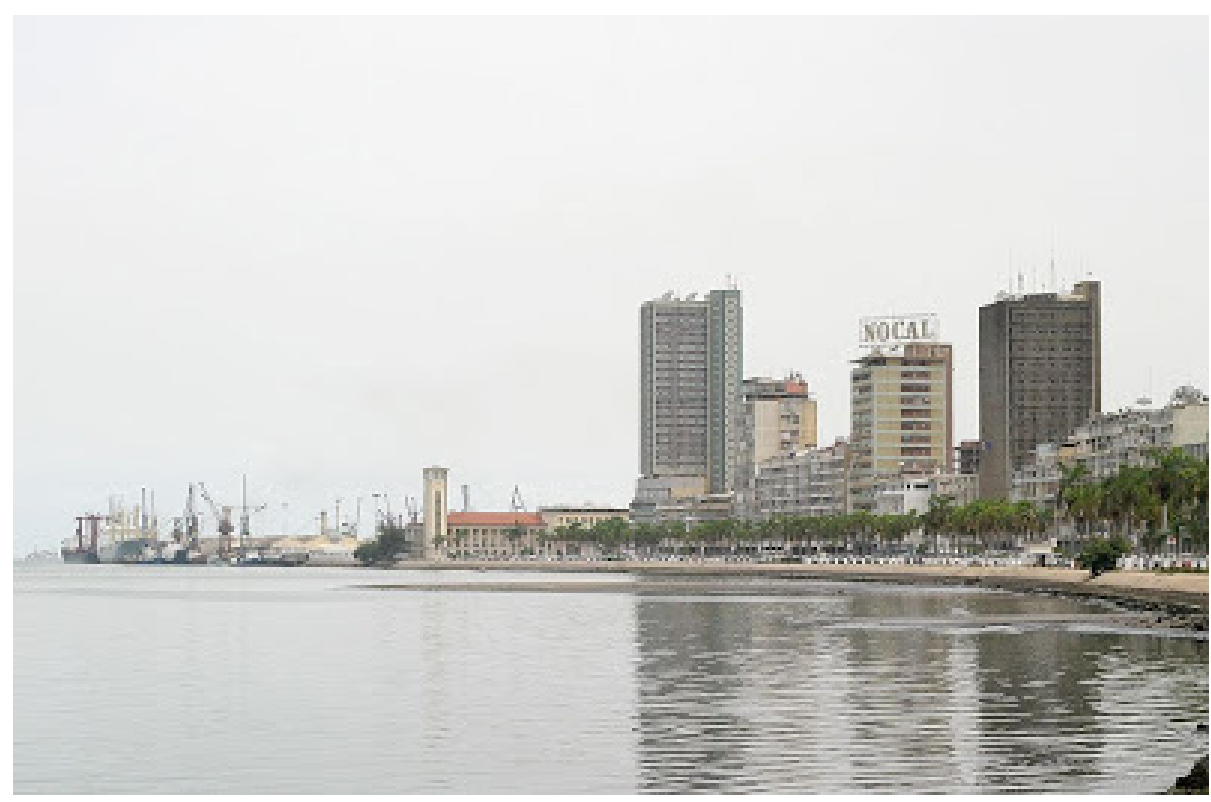

Fonte: Disponível em: <https://angolaimagebank.photoshelter.com/image/I0000iQj2YeLWUuY>. Acesso em: 24 set. 2017.

Sem que ele pudesse concluir, o que estava em cima da escada disse em tom imperativo, próprio dos homens de Angola, mostrando o seu poder ali.

Primeiro você terá que aprender o português. Nem falar o português você sabe. Tem língua tribal, ainda. Como vai subir aqui? Você veio do mato ontem.Vai ter que aprender o português, depois você sobe.

Verificamos ali naquela conversa pontual, aparentemente inocente, entre eles e que nos dado ouvir, o sentido e a importância da língua portuguesa naquele cenário. Estava ali um migrante interno, antigo morador de Luanda, e outro - refugiado - novo morador de Luanda, que veio para a capital atrás de trabalho e renda.

O sociólogo António Santana, em sua entrevista (2008) afirmava que há desvantagens políticas no uso da língua portuguesa, sobretudo no contexto nacional, pois quando se faz o comunicado, por exemplo,

do mais alto mandatário que serve para toda a nação, ele o faz em português e, portanto, nem sempre a sua mensagem é captada pela maioria da nação; já que a maioria da população não entende o português tal como é veiculado pelo presidente. A maioria da população entende o português corrente, o popular, o calão. Também uma desvantagem pelo fato de as populações não poderem acompanhar o debate político; a população, portanto não tem o acesso a informação da maneira que deveria ser desejada, da maneira que deveria ser informada. Porque, embora muitos entendam o português, mas não entende o português pelo discurso que é veiculado pelos políticos. Então isso cria uma certa distância entre a população e os próprios políticos.

Agora, a vantagem que há nisso é que, logicamente, falando o português o universo de indivíduos que vão captar a mensagem é maior do que se tivesse 
a falar em Umbundu ou Kimbundu. Alguns líderes que passaram cá em Angola expressam-se nas suas línguas nacionais, mas só o fazem quando vão em regiões onde se fala essa língua. Porque não pode ir para o Kwanza-norte, ou para Malanje, ou para Luanda, ou para o Bengo, e falar em Umbundu, pois se vai falar vai atingir apenas uma centena de pessoas. E vão até entender isso como uma falta de respeito, é uma agressão.Vem aqui falar com a gente e se põem a falar uma língua que não se fala aqui, no mínimo tem que se falar a língua daqui. A minoria tem que se submeter à maioria, agora falar outra língua não, se calhar numa próxima vez não encontra mais ninguém na praça para ouvir o seu discurso. Essa é uma vantagem do português, que tem um número elevado de pessoas que pode entender.

Nas ruas de Luanda se ouve o calão, o português das ruas que não possui a palavra criança, ali pudemos ouvir mulheres refugiadas da região linguística dos ovimbundu ou mesmo as da língua kimbundu chamarem as crianças de miúdos, como se diz carinhosamente em Luanda, às crianças que se conhece os pais (Fonseca, 2012a). Mas, nos dias que se seguiram e que estávamos nas ruas, atrás de endereços e de locais na cidade, muitas zungueiras nos disseram: ${ }^{10}$

Pergunte aos putos. Ficamos aqui paradas, buscando na vida de mercado, levar Kwanza para casa. Não conhecemos muitos lugares. Mas, eles dizem onde ficam esses lugares. Os putos sabem bem, os lugares que queres. Estão ficam nas ruas, conhecem tudo. São das ruas, se eles não sabem, quem sabe?!

Figura 4 - Zungueiras em Luanda

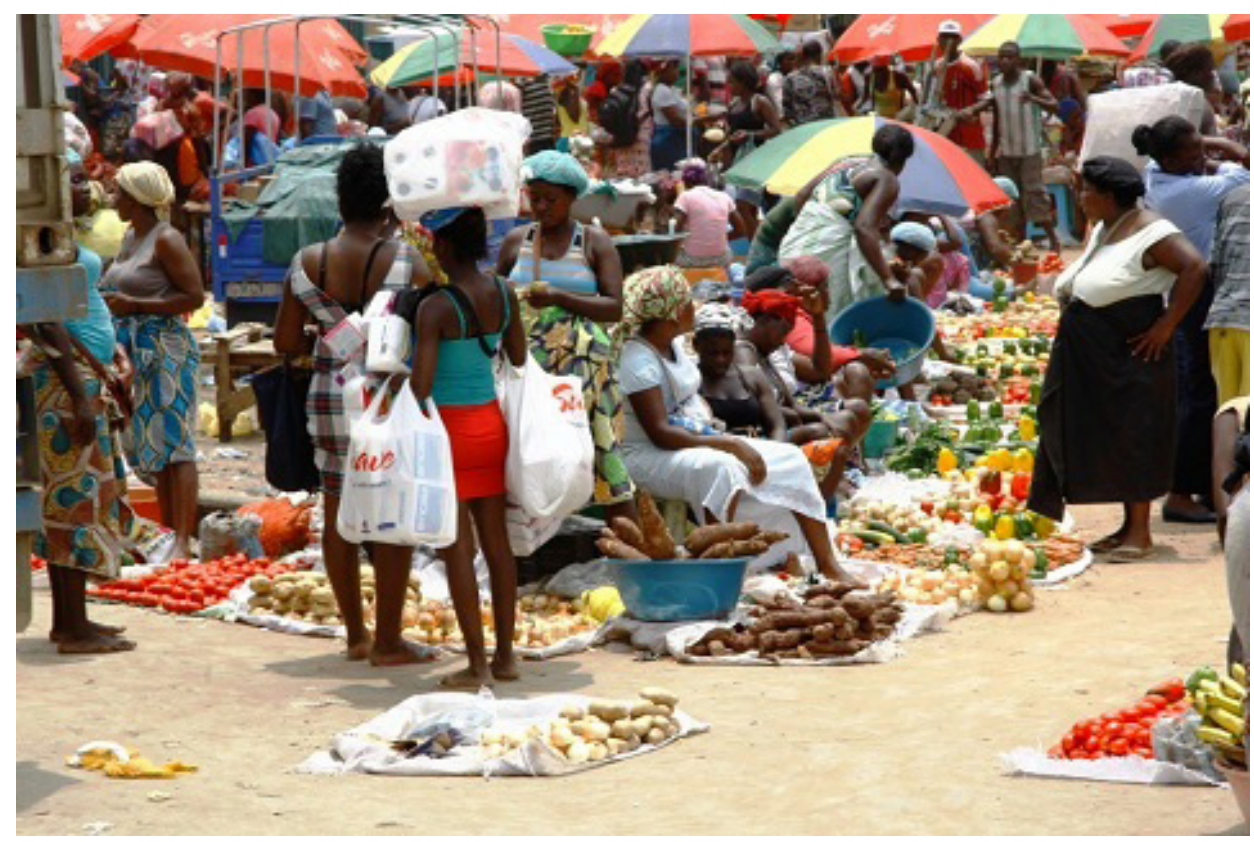

Fonte: Disponível em: <http://www.angolabelazebelo.com/category/zungueiras/>. Acesso em: 24 set. 2017.

10 Zungueiras, nome dado às mulheres que estavam nas ruas mercadejando, isto é, vendendo diversos produtos para o seu sustento, de seus filhos e demais agregados. 
Em vários momentos, como esses que estávamos em busca de um endereço, éramos interrompidos nas ruas, por mulheres ou homens, refugiados ou não, que se encontravam na arte de/do mercado, isto é, na tentativa de vender algo para nós ou para outros que estavam de passagem, e diziam para nós interpelarmos esses meninos que também eram dali. Elas os chamavam assim:

Oh, oh, putos, venha cá! Diga a esses senhores onde fica tal lugar?

Se calhar, senhores, ele leva vocês lá. É só dar uma gasosa para ele.

Oh, oh, puto, venha cá, logo. Rápido!

A língua portuguesa foi mantida, como oficial,pelos dirigentes políticos independentistas angolanos, mas também de outras nações africanas, pois após a década de 1960 ,

procuraram impor a escrita às populações do interior dos seus países. Essas que eram compostas de diversas etnias, com suas tradições culturais e línguas. A tradição oral africana tem sido concebida equivocada e ideologicamente como a que transformou a África em um continente de analfabetos, iletrados e que a tem mantido (Fonseca, 2008, p. 44).

Os líderes independentistas e os dirigentes políticos africanos, todos estudantes em universidades europeias ou que beberam da fonte do conhecimento dos antigos conquistadores europeus, introduziram a tarefa de combater o atraso civilizatório e cultural também com a língua exógena do conquistador europeu. Medida imposta de maneira profundamente ideológica, autoritária e pragmática também por Samora Machel, líder e primeiro Presidente de Moçambique independente, que em 1975, profere no ato de independência de Moçambique a oração: "é preciso matar a tribo para construir a nação" (Fry, 2001, p. 14).

Desse modo, já no início de Moçambique independente de Portugal a maioria do povo é colocada na condição de estranho ao projeto nacional do novo país, pois muitos nunca naquela altura tinham ouvido a língua portuguesa adotada pela FRELIMO ${ }^{11}$ como a língua oficial do novo Estado.

A língua nativa dos antigos que era a difusora de cultura, de construção de conhecimento, de sonhos, de angústias não encontra mais o mesmo sentido do que era antes. A língua forma o espectro mais amplo da constituição do conhecimento de si e do outro. Neste sentido, diz Memmi:

A língua materna é nutrida por suas sensações, suas paixões e pelos seus sonhos, aquela pela qual se exprimem sua ternura e seus espantos, aquela enfim que contém a maior carga efetiva, essa é precisamente a menos valorizada. Não possui dignidade alguma no país ou no concerto dos povos (Memmi, 1977, p. 97).

11 FRELIMO, sigla da Frente de Libertação de Moçambique, partido governista de Moçambique desde a independência em 1975. 
O que se interpreta é que os letrados africanos, em especial seus dirigentes políticos, em sua maioria constituíram ao longo do tempo um novo ethos e habitus a despeito de sua etnia tradicional. Esta realidade sociocultural moçambicana é muito similar à angolana, proposta pelos líderes e dirigentes do MPLA, sobretudo quando se constata que, segundo os dados estatísticos estimados em 2003, havia em Angola cerca de 55\% ${ }^{12}$ de pessoas que não usavam a leitura e a escrita em língua portuguesa para se comunicarem, sendo concebidos como analfabetos pela lógica oficial do Estado Angolano.

No entanto, o que se verifica é que os líderes independentistas angolanos e o partidoEstado-Nação governista conseguiram ser mais eficazes e contundentes em transmitir a língua oficial portuguesa em diversos rincões e grotões étnicos do país em 42 anos de independência mais do que o fez o conquistador português em cerca de 500 anos.

Tanto que em Angola aproximadamente $42 \%$ das crianças com menos de 9 anos tem o português como sua língua nacional; $34 \%$ daqueles que tem idade entre 10 e 19 anos; $18 \%$ dos que tem entre 20 a 29 anos, e $10 \%$ naqueles que possuem mais de 40 anos de idade tem nessa a sua língua de intercâmbio cotidiano. Assim, constata-se que é comum observarmos que jovens kaluandas (naturais étnicos de Luanda) não conhecem nenhuma das línguas nativas de Angola, nem mesmo a sua o Kimbundu (Fonseca, 2008, p. 48).

Inocência da Mata afirma, pautada inclusive pelo contexto da guerra civil angolana, que milhões de pessoas de diferentes etnias angolanas estejam alijadas da cidadania (já tão precária em Angola) pelo fato de não se comunicarem em português. Neste sentido, ela diz:

Deve caber, pois, ao Estado, supostamente preocupado com a Cultura nacional ou o exercício da cidadania, trabalhar (e não apenas através de discursos) para reverter essa situação de exclusão da cidadania de falantes de outras línguas que cada vez se vêm tornando cada vez mais periféricas e folclóricas... Já Boubacar Diarra, técnico da UNESCO que nos anos $80^{13}$ trabalhou no Instituto de Línguas Nacionais, falava da extinção gradual da língua kimbundu... (Mata, 2007, p. 158).

O que se depreende da afirmação de Inocência da Mata é que o Estado Angolano e diversos estados africanos não estão trabalhando para defenderem efetivamente as línguas nativas de milhões de indivíduos em decorrência de diversos fatores, mas sobretudo os de ordem política e econômica. Esta interpretação tem a sua confirmação quando depreendemos da própria da Mata a afirmação de que:

Eleita como "língua oficial" no próprio acto da proclamação da independência no dia 11 de novembro de 1975, o português seria nos anos 80, segundo dados do Ministério da Educação, língua materna de 11\% da população, para, no dealbar do século XXI, se tornar língua materna de $21 \%$ da população

12 Dados fornecidos pela Revista Angola Hoje. Publicação da Fundação Eduardo dos Santos (FESA), Março/Junho, 2003, p. 19. Vale ressaltar que a FESA é a fundação que tem como patrocinador o Presidente da República de Angola, o Engenheiro José Eduardo dos Santos.

13 Enfatizamos que é na década de 1980. 
- língua coexistente (mas não creio que convivente) com outras línguas faladas no território angolano, bantu e não bantu. Sem receio de qualquer rótulo (como o de ser politicamente incorrecta), direi que, então, não foi iniciado um trabalho sério e desideologizado conducente a assegurar "a promoção, o respeito e o uso social e privado" (Declaração Universal dos Direitos Lingüísticos, Introdução) das línguas faladas no território angolano, disposições necessárias à garantia de universalismo, igualdade e harmonia (Mata, 2007, p. 154).

O português continua sendo um termômetro social do processo de ascensão e de distanciamento de enormes contingentes populacionais que não dominam a escrita e a língua oral oficial portuguesa. Na concepção de Bender,

o sistema colonial português dominou os africanos nos sectores rural e africano sem os absorver; esgotou completamente os africanos sem jamais os ter integrado plenamente no sistema (Bender, 2004, p. 356).

Consideramos em artigo anterior, que

a tese de Bender é que a assimilação não ocorreu de fato na população angolana até porque não havia total interesse dos portugueses que os africanos, particularmente angolanos e moçambicanos, aprendessem e assimilassem a sua cultura e, neste sentido, a própria língua, inclusive pelo fato de que os portugueses nunca ultrapassaram a uma população de $5 \%$, por exemplo, em Angola, tendo também em números absolutos uma singela minoria na realidade moçambicana, durante o período de conquista colonial (Fonseca, 2008, p. 51).

A língua do conquistador tornou-se por adesão e por necessidade um dos elementos de sobrevivência e de resistência que marcaram e reconstruíram a identidade sociocultural da população residente nas capitais coloniais africanas. Essa dinâmica identitária forjada em decorrência do contato mais latente entre os nativos e os conquistadores e, ainda, com os seus descendentes europeus nessas capitais africanas, propiciaram também o uso estratégico das línguas europeias para o engajamento no jogo das nações e do mundo que se globaliza nos estertores da guerra fria (Ki-Zerbo, 2006).

Se de um lado, a língua do conquistador foi usada enquanto estratégia política pelos dirigentes independentistas e pelos Estados africanos nas décadas de 1960 e 1970 com o nítido objetivo de ampliar as suas fronteiras linguísticas, comerciais e políticas; por outro lado, o uso dessas línguas também veio a acarretar prejuízos identitários, sociais e subjetivos para a grande massa populacional que foi convertida em estrangeira em sua própria pátria, sobretudo quando tiveram que se refugiar nas suas cidades-capitais, como o que ocorreu em Luanda.

Em suma, vale salientar que:

A língua portuguesa foi apropriada pelos líderes independentistas angolanos como a língua oficial do novo Estado. Assim, ela convive com as demais línguas nacionais e étnicas em nítida concorrência. No entanto, ela se afirma cotidianamente nos altos escalões do governo e da burocracia, mas também 
na literatura e na música, portanto no imaginário sociocultural e na realidade concreta como uma língua de prestígio e que hierarquiza grupos, segmentos e indivíduos, particularmente porque ela está associada ao mercado de bens materiais e simbólicos e que define o lugar que o indivíduo, grupo ou segmento social ocupa na estrutura e no cotidiano angolano. A língua portuguesa organiza e estrutura a vida administrativa e gerencial em Luanda e no restante do país, mas não é a língua que monopoliza o mercado das ruas, na medida em que não é a língua do candongueiro e das zungueiras (Fonseca, 2012a, p. 5).

Neste sentido, o linguista e reitor da Universidade Técnica de Angola (UTANG), o Dr.Victorino Reis, que é somente falante de sua língua étnica natal, afirmou em 2008.

Em Angola, nós temos umas particularidades, fala-se em grupos sociolingǘsticos que normalmente associa-se ao local de nascimento, que é a pertença étnica da pessoa. Eu felizmente sinto-me pertencer ao grupo étnico da localidade onde de fato nasci. Porque em termos práticos nem sempre isso corresponde; nós podemos nascer num lugar ocasionalmente [...] Eu digo que a língua portuguesa é língua oficial e língua veicular, mas nunca digo que a língua portuguesa seja língua nacional. Não é uma questão pelo fato dela ser língua de outra origem, ser língua do colonizador. Eu sou apologista da tese que é defendida por um lingüista que diz que a língua nacional é aquela que nós temos um sentimento de pertencimento ou um sentimento de posse mais marcado; independentemente dela ser uma língua oficial ou não. Então é nessa perspectiva que Angola separou-se dos conceitos de língua oficial e língua nacional. Portanto, o português eu digo sim que é a língua oficial, a língua de todos nós, mas não é a língua nacional.

Consideramos que a realidade sociolinguística afirmada pelos entrevistados e informantes acima nos faz interpretar outra situação importante para este processo instaurado pela língua portuguesa enquanto uma língua que dialoga com as demais de Angola, que é o sentimento de pertença que se tem com a língua e como se atribui a esta realidade o seu sinal diacrítico, na medida em que a língua constrói o valor da etnicidade a partir do que se fala, se ouve e se constata do mundo, a cultura e a tradição, bem como com os antepassados e as forças originárias do universo cosmológico bantu ${ }^{14}$.

Não se invoca o passado imemorial com a língua portuguesa. Ela não acessa o particularismo referenciado na energia presente no muntu ${ }^{15}$ e nem estabelece uma

14 Cosmologia africana dos bantu-kongo: princípios de vida e vivência.Ver: SANTOS, Tiganá Santana Neves. A tradução de sentenças em linguagem proverbial e o diálogo com o pensamento bantu-kongo a partir de Bunseki Fu-Kiau. Disponível em: <https://www.revistas.usp.br/clt/article/viewFile/115268/112953>. Acesso em: 24 set. 2017.

15 Muntu, palavra na língua bantu para designar o ser humano. 
ligação primordial com a sociedade ubuntu ${ }^{16}$, presente nos angolanos e na maioria dos refugiados oriundos dos países vizinhos que estão vinculados por uma diversidade de línguas que os fazem conversarem não pela simples palavra, supostamente abstrata que é o português, mas pelo olhar e pelo sentimento de pertencimento que vem desde os antigos.

Outra questão importante deste fenômeno que é a migração e o refúgio tem sido a explosão demográfica em Luanda. Por mais complexa que possa ser está vinculada a múltiplos fatores, entre os quais pela guerra civil, o que implicou em diversos vazios populacionais existentes em amplas áreas de Angola. Além do que esta densidade demográfica em Luanda é resultado deste movimento campo-cidade-capital que é recente na história angolana.

Não podemos somente considerar que este fenômeno social é determinado pelas guerras que estiveram deslocando populações refugiadas, mas atualmente muitos vieram para a capital em busca de emprego e de dinheiro para manter a sobrevivência individual ou de toda a parentela de sangue e de afinidade ${ }^{17}$.

Segundo a interpretação realizada por Miguel Ângelo da Silveira Vieira ${ }^{18}$, a explosão demográfica trouxe problemas sociais para Luanda. Ela ocorreu pelo fator guerra,

mas também pelo fator oportunidade. Além do que em Luanda não há minas como em outros lugares do país e, ainda, aqui em Luanda, se você faz isso, faz aquilo, tem-se um almoço garantido, tem-se um jantar. Então as pessoas não se preocupavam com comida.

Em rápida conversa com um mercador refugiado na Avenida Samba, próximo ao Hospital Maria Pia (atual Hospital Josina Machel), onde dava para se avistar o enorme memorial construído para manter a memória de Agostinho Neto, o pai fundador da Angola independente e primeiro presidente de Angola, ele nos dizia:

Como voltar para o trabalho no campo. Lá trabalhar com o regime das estações de água, ficar atento ao período seco e à plantação. $\mathrm{O}$ governo não protege a terra e nem quem tá nela. Quem vive em Luanda e quem nasceu aqui, o Kaluanda, não sabe o trabalho que dá para chegar até o tempo de colher, de tirar o fruto da terra.Aqui, quem nasce aqui, somente sabe comer. Aqui ninguém morre de fome, pois se come, sempre tem alguma coisa para comer. Quem tá na plantação do interior pode colher uma mina se não ficar de olho aceso.

16 Ubuntu, palavra na língua bantu para designar a concepção de pertencimento e de identidade: "sou quem sou porque somos todos nós. Existo porque nós existimos". Esta concepção traz em seu cerne a solidariedade, a reciprocidade; a vida em comum só faz sentido se estivermos unidos e identificados.

17 Destaca-se este fato, pois em Angola há relações parentais fundadas na estrutura de família extensa, em que se encontra a figura do agregado.

18 Fragmento de entrevista concedida em maio. 
Figura 5 - Hospital Maria Pia/ Hospital Josima Machel

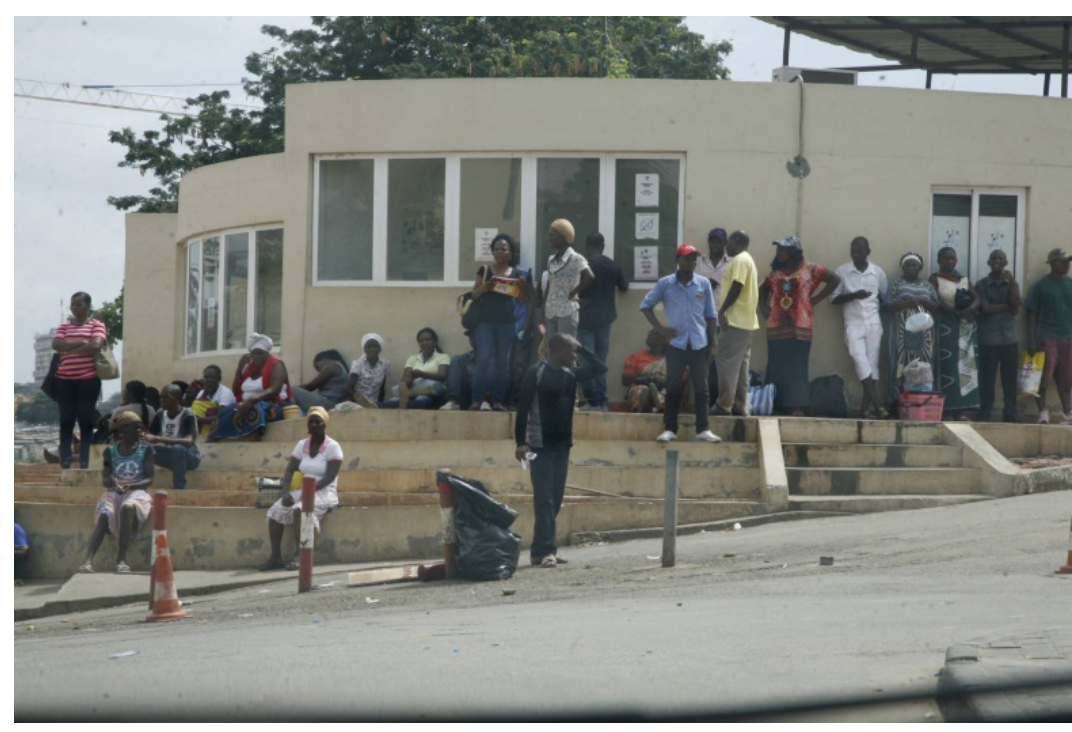

Fonte: Disponível em: <https://www.google.com.br/search?q=hospital+maria+pia+luanda + fotos+imedia $\%$ C3\%A7\%$\mathrm{C} 3 \%$ B5es\&client $=$ gmail\&rls=aso\&authuser $=0 \& \mathrm{dcr}=0 \& \mathrm{tbm}=$ isch\&tb\#imgrc $=$ FWkYdVN2aLg30M: $>$. Acesso em: 24 set. 2017.

No entendimento do sociólogo Antônio Bernardes de Miranda, o fator guerra tem que ser considerado como o mais importante para a grande migração da população que se refugiu em Luanda, mas o fato dela não voltar para as áreas de origem no meio rural após o fim da guerra está em virtude:

Primeiro do dinheiro, o dinheiro circula aqui. Segundo, a questão do individualismo. Luanda, provavelmente, é a única cidade onde a pessoa pode viver de uma forma anônima. Você vê aqui cada um perseguindo seu interesse e também a expressão de prestígio é só em Luanda. Logo a explosão ou o êxodo rural é provocado não só pelo fim da guerra, mas também pelo fato de que é o meio onde as pessoas podem viver de uma forma anônima: você pode fazer tudo que quiser.

Esta mesma leitura vale para os demais imigrantes africanos, europeus, asiáticos e americanos, entre os quais os brasileiros, que se dirigem para Luanda contribuindo com a explosão demográfica, aí está o fator fim da guerra, mas junto com ele, a possibilidade de conquistar fortuna diante do grande boom econômico de Angola. E o boom econômico angolano passa inevitavelmente por Luanda, pois ela é a capital política, econômica e financeira do país.

Quem está em Luanda, mesmo trabalhando pouco ou não tendo qualificação social (falta de fluência na língua portuguesa, por exemplo) e, ainda, possuir uma péssima qualificação profissional para os padrões do mercado formal angolano, consegue a despeito dos problemas se manter no mercado informal que se ergue vertiginosamente nas ruas da cidade-capital todos os dias, contando com mulheres, homens e crianças vendendo produtos de todos os tipos, sobretudo os oriundos da China e de Taiwan. Ressaltamos que os produtos chineses e de outros países asiáticos industrializados tem transformado 
os valores materiais, simbólicos e econômicos desta população originária do campo no ambiente citadino de Luanda ${ }^{19}$.

Não precisa ter qualificação profissional e social para manter-se em Luanda. Mas, esta não é a realidade para quem continua no interior do país, pois no meio rural há necessidade de se plantar e esperar os períodos de chuva, a produção do solo para se alimentar e comprar outros bens básicos. Porém, na capital do país isto não é necessário, a cada dia se conquista o almoço e o jantar e não se depende da natureza para lhe suprir as necessidades vitais, ele se torna dono do seu destino e de sua alimentação.

Nestas condições, em Luanda os produtos chineses e de outros países asiáticos impõem aos jovens imigrantes do interior do país o desejo real de não mais plantar para comer. O retorno ao meio rural fica cada vez mais dificil, ou melhor, até impossível para essa juventude (FESA, 2005).

Para os nossos interlocutores a explosão demográfica existente em Luanda não afetará significativamente a ordem política, institucional, mas poderá afetar em longo prazo os rumos democráticos do país (Vidal;Andrade, 2007). Segundo Miguel Â. S.Vieira,

esta explosão não é boa para a democracia. Os filhos dos imigrantes estão todos aqui numa única voz, que é a voz de quem eles vêem e ouvem, que é a voz de quem lhes dá emprego, é a voz de quem lhes dá comida, a voz de quem lhes dá cerveja, de quem promete emprego; que pode fazer com que haja uma maioria absoluta. Não é o melhor nem é o desejável para Angola, do meu ponto de vista. Então mesmo estando na África, temos uma coisa muito forte, que é o fator étnico como fator de voto, como uma vantagem para o voto. Luanda desestabiliza um pouco este fator étnico por causa do ambiente cultural. E de forma indireta, a experiência que eu tenho, é de que se vai trabalhar neste sentido, para as zonas onde há este fator étnico. Com o andamento das coisas pode-se tentar melhorar em relação a isso, mas melhorar unilateralmente, dentro do programa de determinada força política.

Na concepção de Albano V. L. Ferreira, a explosão demográfica,

impõe obviamente nas cidades uma multiplicidade de problemas com dificuldades na gestão pública. Hoje a gestão de cidades é quase uma especialidade de ação, de desenvolvimento. Mas, ela em si não oferece riscos ao processo democrático do país.

Já para Antônio Bernardes de Miranda, que acompanhou o processo eleitoral em 1992, na condição de Presidente da Comissão Eleitoral, e na última eleição das Legislativas ocorridas em setembro de 2008, considerou que esta explosão demográfica:

Não diria afetar, mas contribui para a reforma da democracia. Por que só

19 Fato que deverá merecer uma atenção especial de pesquisadores locais e estrangeiros em curto prazo, pois se altera no cotidiano das ruas de Luanda não somente a identidade pessoal, mas também a étnica, a cultural, a social, mediante o trabalho de revendedor de bens efêmeros ou mesmo de utensílios domésticos de pouca durabilidade, sem nenhuma assistência técnica e nem as orientações em língua portuguesa. 
Luanda pode controlar o Estado. E graças a essa explosão demográfica, temos aqui pessoas que não estão aqui para brincar, mas para aprender.A administração está aqui, as escolas estão aqui, os professores [...] Então, estão aqui para aprender alguma coisa também. E isso não incomoda a democracia, mas incomoda o Estado, porque as pessoas aqui abrem mais os olhos, combatendo as injustiças do Estado. Então, antes, pelo contrário, é um progresso.

Em novembro de 2008, também a Fundação Eduardo dos Santos (FESA) promoveu as suas Jornadas Científicas tendo como tema a preocupação urbana, em especial com a cidade de Luanda e com outras cidades do interior e do litoral angolano. Constatávamos nestas jornadas que o governo angolano em conjunto com esta fundação promovia o deslocamento de grandes contingentes populacionais de Luanda, residentes em musseques, levando-os para áreas inóspitas, de modo semelhante como se faz no Brasil com os conjuntos habitacionais sendo construídos nas mais longínquas periferias.

Todavia, se essa política era interessante para os membros do governo e setores de renda média e alta envolvidos na iniciativa privada em Luanda, para alguns refugiados e migrantes oriundos das áreas atingidas pela guerra ou mesmo naquelas que os investimentos do governo, ainda, não tinham atendido adequadamente, e localizados nas imediações do largo do Kinaxixi e da estatua da Rainha $\mathrm{Nzinga}^{20}$, nos diziam a jeito:

Sair de Luanda, nem pensar. Não saio mais de Luanda, aqui há tudo. Se tem sofrimento? Tem, sim e muito. Sou mal visto, me sinto mal, por isto também. Mas, não é só isto.Aqui também se tem a alegria de saber que não morre.Você é atendido por alguém com algo para você comer. Você consegue dinheiro para comer. Vende qualquer coisa, mas vende. Eu sempre me pergunto, se o senegalês consegue vender aqui? Por que eu não vou conseguir. $\mathrm{O}$ de Luanda não vende nas ruas, mas compra deles e de nós angolanos também.

Outro nesta mesma zona da cidade, falava de maneira jocosa e objetiva:

O que fazer no interior? Si calhar, morrer de fome só si for. A guerra acabou com tudo, nem água para se tomar. Aqui, em Luanda, si come fungi, si come peixe, si come folha, si come fruta, si come sempre alguma coisa.Voltar para a casa que casa? A guerra acabou com tudo, com a família, que ficou dispersa. Agora juntar tudo de novo é bem difícil. Aqui no Kinaxixi, por exemplo, se vê a Rainha Nzinga e se tem a $\mathrm{Cuca}^{21}$. Na aldeia não tem nada disso para ver, beber e inspirar.

20 Rainha Nzinga do Reino Ndongo, líder política e militar que combateu os portugueses e holandeses no século XVI. Imagem disponível em: <https://www.google.com.br/search?q=kinaxixi+luanda + rainha + nzinga $+\mathrm{e}+$ cuca\&client $=$ gmail $\& \mathrm{rls}=$ aso\&authuser $=0 \& \mathrm{dcr}=0 \& \mathrm{tbm}=\mathrm{isch} \& \mathrm{tbo}=\mathrm{u} \&$ source $=$ univ\&sa $=$ X\&ved $=0$ ahUKEwiF5oWc9M3WAhXIkpAKHZUyAA0Q7AkIMw\&biw $=13$ 66\&bih=662\#imgrc $=$ Q9XKNZCoS4xTxM>. Acesso em: 24 set. 2017.

21 Cuca, cerveja nacional de Angola. A cervejaria Cuca fica situada no largo do Kinaxixi. 
Figura 6 - Estátua da Rainha Nzinga e Cervejaria Cuca

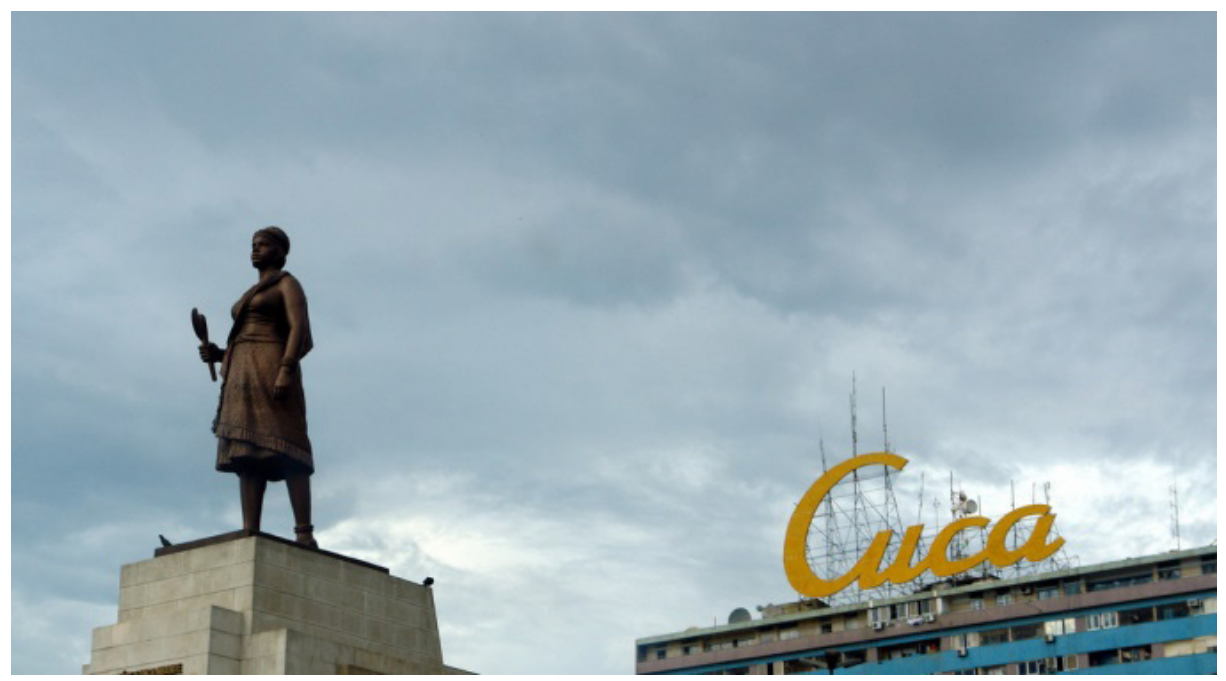

Fonte: Disponível em: <https://www.flickr.com/photos/unroyal/2438808949>.

O governo também está liberando áreas nas proximidades de Luanda para construtoras e incorporadoras para a construção de casas para funcionários públicos e membros dos segmentos intermediários da capital a fim de atender o enorme déficit habitacional.

Mas esta dinâmica dicotômica entre campo-cidade revela o quanto Angola tem a contribuir com Luanda se houver uma política eficaz e duradoura para atrair enormes contingentes populacionais para as suas regiões e áreas de origem cultural e simbólica. De modo a fazer com que tanto a população refugiada das guerras possa voltar para as suas antigas vilas, aldeias e cidades, e a migrante nacional possa também obter a propriedade da terra das mãos do Estado que a estatizou quando da independência e da instalação do regime socialista na década de 1970.

Consideramos que o maior estímulo ao retorno da população angolana não kalunda para deixar Luanda é a constituição de diversas ações sociais e públicas, mas que tenha como foco a certificação e titulação individual da terra para esses retornados, mas quanto aos de outras nacionalidades africanas e europeias a proposta tem que ser de outra forma, justamente para não se vender a terra que é inscrita na cultura nativa como um bem social, inalienável e comunitário aos estranhos, sobretudo porque não se pode correr o risco de perder a soberania e autodeterminação dada pela propriedade da terra.

\section{Referências}

ANDRADE, Mario de; Ollivier, Marc. A guerra em Angola. Lisboa: Seara Nova, 1974.

BENDER, Gerald. Angola sob o domínio português: mito e realidade. Luanda: Nzila, 2004.

FONSECA, Dagoberto José. De migração em migração se constroem impérios, reinos e cidades: o africano no contexto da globalização. In: MALOMALO, Bas’Iele; FONSECA, Dagoberto J.; BADI, Mbuyi Kabunda (Org.). Diáspora africana e migração na era da globalização: experiências de refúgio, estudo, trabalho. Curitiba: CRV, 2015. 
. De onde parte o nosso olhar interpretativo? da margem oriental do Atlântico. In: CARDOSO, Clodoaldo M. (Org.). Convivência na diversidade: cultura, educação e mídia. Bauru, SP: Cultura Acadêmica, UNESP/FAACBauru, 2008.

Você conhece aquela? a piada, o riso e o racismo à brasileira. São Paulo: Selo Negro, 2012.

. As línguas nacionais e o prestigioso português em Angola. In: SIELP - Seminário Internacional de Ensino de Língua Portuguesa, 2., 2012, Uberlândia. Anais... Uberlândia: EDUFU, 2012a. Disponível em: <http://www. ileel.ufu.br/anaisdosielp/wp-content/uploads/2014/06/volume_2_artigo_083.pdf>.Acesso em: 29 set. 2017.

FRY, Peter. Apresentação. In: FRY, Peter (Org.). Moçambique. Rio de Janeiro: UFRJ, 2001. p. 13-20.

FUNDAÇÃO EDUARDO DOS SANTOS. A juventude face à reconstrução e ao desenvolvimento do país. In: JORNADA TÉCNICO-CIENTÍFICA, 9., 2005, Luanda. Anais... Luanda: FESA, 2005.

GEERTZ, C. A interpretação das culturas. Rio de Janeiro: Guanabara, 1989.

O Saber Local: Novos Ensaios em Antropologia Interpretativa. Petrópolis, RJ:Vozes, 1998.

GOLAN, Tamar; RON, Tamar. Encontros em Angola: o homem e a natureza na sombra da guerra. Luanda: Chá de Caxinde, 2007.

HUNT, Lynn (Org.). A Nova História Cultural. São Paulo: Martins Fontes, 1992.

JOR GE, Manuel. Para compreender Angola - da política à economia. Lisboa: Dom Quixote, 1990.

KI-ZERBO, Joseph. Para quando a África?: entrevista com René Holenstein. Rio de Janeiro: Pallas, 2006.

LE GOFF, Jacques (Org.). A Nova História. São Paulo: Martins Fontes, 1990.

MALOMALO, Bas'Iele; FONSECA, Dagoberto J.; BADI, Mbuyi Kabunda (Org.). Diáspora africana e migração na era da globalização: experiências de refúgio, estudo, trabalho. Curitiba: CRV, 2015.

MATA, Inocência. A literatura africana e a crítica pós-colonial: reconversões. Luanda: Nzila, 2007.

MEMMI, Albert. Retrato do Colonizado precedido pelo retrato do colonizador. Rio de Janeiro: Paz e Terra, 1989.

MICHEL, Miguel Francisco. Nuvem negra - o drama do 27 de maio de 1977. Lisboa: Editores associados, 2007.

MOORE, Carlos. A África que incomoda: sobre a problematização do legado africano no quotidiano brasileiro. Belo Horizonte: Nandyala, 2010.

PEREIRA, Luena N. Nunes. Os Bakongo de Angola: etnicidade, religião e parentesco num bairro de Luanda. Rio de Janeiro: Contra Capa/FAPERJ, 2015.

REVISTA ANGOLA HOJE. Publicação da Fundação Eduardo dos Santos (FESA), Março/Junho, 2003.

RICOEUR, Paul. Interpretação e Ideologias. Rio de Janeiro: Francisco Alves, 1990.

O Conflito das Interpretações: Ensaios de Hermenêutica. Rio de Janeiro: Imago, 1978.

ROQUE, Fátima Moura. Construir o futuro em Angola. Oeiras, Portugal: Celta, 1997.

SANTOS, Tiganá Santana Neves. A tradução de sentenças em linguagem proverbial e o diálogo com o pensamento bantu-kongo a partir de Bunseki Fu-Kiau. Disponível em: <https://www.revistas.usp.br/clt/article/viewFile/115268/112953>. Acesso em: 24 set. 2017.

VIDAL, Nuno; ANDRADE, Justino Pinto de. O processo de transição para o multipartidarismo em Angola. Luanda, Lisboa: Firmamento, 2007.

VOVELLE, Michel. Ideologias e mentalidades. São Paulo: Brasiliense, 1991.

\section{Entrevista}

António Santana, 2008. 


\section{Refugees and migrants at contemporary Luanda}

Abstract

This paper addresses the discussion on refugees and migrations to depict population displacements in Angola. We examine Luanda, considered the most expensive capital of the world. The city was designed by the Portuguese conquerors to be a summer resort town and have a maximum of 500,000 inhabitants. However it has more than six million people today. Most are internal migrants from rural areas, refugees from the independence and civil wars, speakers of six major native languages and more than thirty language variants originating from the national territory. In this sense, the Portuguese language also becomes a challenge and an achievement for refugees who do not master the language, but need it in Luanda. The capital has also received African foreigners of French and English languages, such as the Namibians, Congolese, Zambians, Senegalese, and from other regions of the world, especially Brazilians, Portuguese, Cubans and Chinese.

Keywords: Luanda, refugees, wars, peace, migrations.

\section{Refugiados y migrantes en la Luanda contemporánea}

\section{Resumen}

El artículo, al iniciar el debate sobre los refugiados y las migraciones, expone los desplazamientos poblacionales presentes en Angola. Lanzamos nuestra mirada hacia Luanda, considerada la capital más cara del mundo, después de haber sido diseñada por los conquistadores portugueses para ser una ciudad de vacaciones y tener un máximo de 500 mil habitantes, sin embargo actualmente posee más de seis millones de personas. La mayoría son migrantes internos, oriundos de zonas rurales, refugiados de las guerras de la independencia y las guerras civiles, hablantes de seis grandes idiomas nativos y más de treinta variantes lingüísticas originarias del territorio nacional. De esa forma, la lengua portuguesa se convierte también en un desafío y una conquista para los refugiados que no la dominan y la necesitan en Luanda. Esa capital, que también ha recibido extranjeros africanos de las lenguas francesa e inglesa, como Namibia, Congo, Zambia, Senegal y otras partes del mundo, especialmente brasileños, portugueses, chinos y cubanos.

Palabras clave: Luanda, refugiados, guerras, paz, migraciones. 